\title{
FACTORS INFLUENCING THE UPTAKE OF FLOOD MITIGATION MEASURED IN BUDALANGI, KENYA
}

\author{
Sylvan ODIDI ${ }^{1}$, Sarintip TANTANEE ${ }^{2}$ D, Korakod NUSIT ${ }^{3 *}$, Panu \\ BURANAJARUKORN ${ }^{4}$
}

DOI: 10.21163/GT_2020.151.07

\begin{abstract}
:
The severe climate change necessitates the people who live in the flood prone areas, to implement the flood mitigation measures in their communities. There are various factors that influence the uptake of mitigation measures; these factors are very vital in the design of community development plans. This research aims to assess the relationship between sociopsychological factors and the people's uptake of flood mitigation measures in Budalangi, Kenya. The socio-psychological factors include - (1) the perceived self-efficacy, (2) the flood experience, (3) the perceived response cost, (4) the worry, and (5) the perceived flood consequences. Primary data was obtained from one hundred households in Budalangi through face-to-face interviews. The statistical analysis and Spearman correlation test were employed for evaluating the interviewed data. The analysis results revealed that the uptake of mitigation measures is greatly affected by the self-efficacy. The flood experience and worry contribute moderate and weak positive influences, respectively. The perceived response cost has negative influences. The perceived consequence is statistically insignificant factor. The identified barriers of mitigation schemes implementation include incentive, financial issue, lack of technology, communication and information transferred. These impediments required immediate attentions to improve the mitigation management at household's level. The future research should focus on household's perspectives if the effective mitigation measures are implemented.
\end{abstract}

Key-words: Socio-psychological factors, Flood, Protection Motivation Theory, Flood Mitigation Measures.

\section{INTRODUCTION}

The previous research shown that, in 2050, approximately two billion people or more will be affected by flood from the frequent rainfall, snow and ice melting (Bogardi, 2004). Globally, communities along the rivers are experiencing an exponential rise in flood risks (Ceola et al., 2014; Costache, 2014). The anthropogenic factor has a high impact on the degree of flood damages (Elme et al., 2012). The flood risk potential increases with the rise in the number of properties in floodplains (Taki et al., 2013; Nusit et al., 2019). Moreover, flooding event impedes social and financial developments.

\footnotetext{
${ }^{1}$ Department of Industrial Engineering, Naresuan University, 65000, Tha-Po, Mueang, Phitsanulok, odidisylvan@gmail.com

${ }^{2}$ Centre of Excellence on Energy Technology and Environment, Department of Civil Engineering, Naresuan University, 65000, Tha-Po, Mueang, Phitsanulok, Thailand, sarintipt@nu.ac.th

${ }^{3}$ Centre of Excellence on Energy Technology and Environment, Department of Civil Engineering, Naresuan University, 65000,Tha-Po, Mueang,Phitsanulok, Thailand, korakodn@nu.ac.th

${ }^{4}$ Department of Industrial Engineering, Naresuan University, 65000, Tha-Po, Mueang, Phitsanulok, Thailand,korakodn@nu.ac.th
} 
The floods significantly influence the country developments and people well-beings. They pose a profound threat to education, health, infrastructure, economic growth, and environment.

Budalangi in Busia County, Kenya, located at the mouth of Nzoia river. According to its geographical conditions, the area is prone to be affected by flooding disasters, which may result in huge economic and financial losses. For example, in May 2018, 4,000 farmers were affected by flood and 39,000 acres of crop were destroyed (NTV, 2018). In response to that incident, Government of Kenya has initiated and implemented the flood mitigation projects. The Western Kenya CDD and Flood Mitigation Project (2007-2016) was one of the projects equipped by the Government of Kenya at that time. The project includes many components such as dike and weir dam constructions. The public mitigation measures could not eradicate the entire damages; however, private mitigation measures contribute a significant role in damages reduction. Private mitigation measures formed the part and parcel of contemporary flood risk management. (Osberghaus, 2015).

The previous studies related to floods and flood mitigation measures within the Budalangi Constituency focused on - (1) comparative study of flood resilience (Atieno, 2015), (2) understanding the extreme climatic events (Huho \& Kosonei, 2014), (3) the flood root causes and community interventions (Okumu, 2017), (4) the analysis of flood impact based on gender differences (Mukuna, 2015), and (5) the perceptions of household on impacts (Opondo et al., 2014). However, very little attention has been directed to the detailed assessment of the factors that influences the uptake of mitigation measures at household level. Therefore, the objective of this study is to evaluate the relationship between the socio-psychological factors and the uptake of flood mitigation measures in Budalangi, Kenya.

In this research, the socio-psychological factors include the perceived self-efficacy, the flood experience, the worry, the perceived response cost, and the perceived flood consequences.

\section{PROTECTION MOTIVATION THEORY}

This research was characterized based on the Protection Motivation Theory (PMT), which was developed by Rogers in 1975 (1983). At first, the PMT was used to explain the self-protection behavior of people based on their health risks. The PMT was later improved by Miler et al. (2000). Even though, the PMT was initially developed for health protection scheme, its uses were extended to other fields of study. Grothmann et al. (2006) adopted the PMT for assessing the personal protection plan on flood disaster. According to the Grothmann's framework, individual who have ability to protect themselves from flood will implement more measures. In addition, individual who perceives the mitigation measure will effectively reducing flood damages and losses.

The flood-experienced people are likely to implement the mitigation measures, to avoid or reduce the damages associated with floods. In addition, households that worry about the flood consequences will be motivated to implement mitigation measures to protect themselves. The individual who perceive that the cost of implementing mitigation measure is high and time consuming is unlikely to take mitigation measures.

Regarding to the perceived flood consequences, individual who perceive the impacts of flood will be encouraged to implement the mitigation measures. On the other hand, the perceived flood damage does not influence these intentions, because it does not automatically convert to high levels of preparedness. However, the implementation barriers 
are exit. This includes the lack of incentives, limited information transferred, and the financial status of the household. The example of previous research which employed the PMT for the household behaviors assessment includes Grothmann, et al. (2006), Bubeck et al. (2013), Poussin et al. (2014), Osberghaus (2015), and Babcicky et al. (2017).

\section{MATERIALS AND METHODS}

\subsection{The study area}

Budalangi located in the Western part of Kenya, in Busia County (see Fig. 1). It lies between the latitude $0^{\circ} 30^{\prime \prime} \mathrm{S}$ and $0^{\circ} 11^{\prime} 30^{\prime \prime} \mathrm{N}$, the longitudes $33^{\circ} 56^{\prime} 30^{\prime \prime} \mathrm{W}$ and $34^{\circ} 10^{\prime} 30^{\prime \prime}$ E (Muku et al., 2013). The study area was selected because of it situated in the flood prone area (Opere, 2013; Opondo, 2013). The study area has a very flat topography. The average annual rainfall of the area ranges from $750-1,015 \mathrm{~mm}$ (Onywere, 2011). It is about 185 square-meter wide. The total population of the study area is 66,732 with the number of households standing at 15,245 (KNBS, 2010).

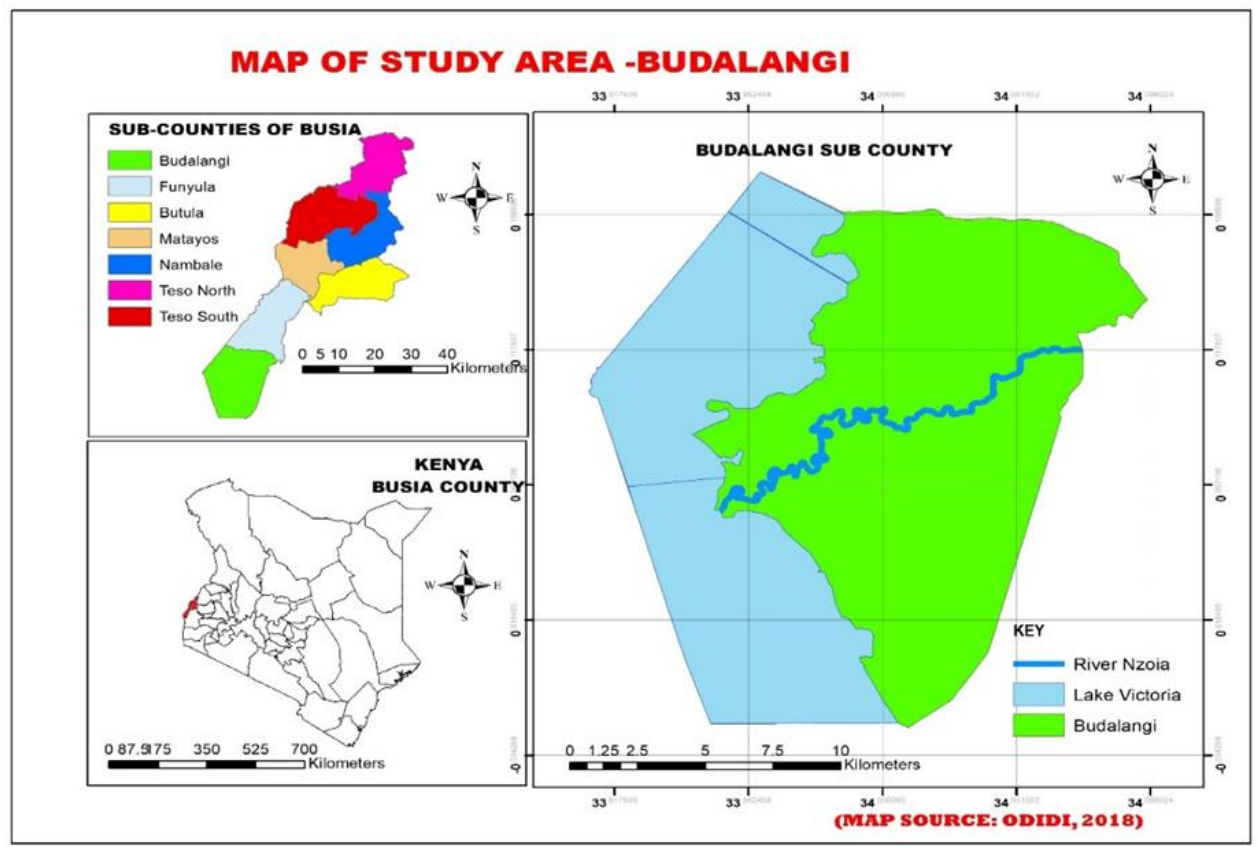

Fig. 1. The study area.

\subsection{The sample sizes}

To determine the sample size, Yamane's sampling method was adopted (Yamane, 1973). The sample size calculation based on Yamane's method is expressed in Eq. 1.

$$
\mathrm{n}=\mathrm{N} /\left(1+\mathrm{Ne}^{2}\right)
$$

in which, $\mathrm{n}$ is the sample size, $\mathrm{N}$ is the population (households), and $\mathrm{e}$ is the margin of error $(0.1,0.05$ or 0.01 ). 
The sample size in this research was calculated with $\mathrm{e}=0.1$. Therefore, one hundred household was obtained from Eq. 1.

\subsection{Sampling method}

Scientific research attaches great importance to the problem of sampling, nowadays there are specific procedures according to each field (Şarpe and Haidu 2017 - an example in hydrology; Nistor et al., 2019 - an example in soil sciences). The present study employed a multistage sampling method for the selection of the sampling sites and the sizes of sample at each site. Multistage Sampling is one of the sampling techniques which the size of sample is reducing for the subsequent analysis stage. In the first stage, Busia county was chosen. In the second stage, Budalangi constituency was purposively chosen because it is prone to flood event. Then, Budalangi was divided into four strata - central Bunyala, south Bunyala, west Bunyala, and north Bunyala. In the third stage, 10 sub-locations were randomly selected. These sub-locations were previously affected by the flood events. In the final stage, the sample size of the interviewed household was calculated according to the number of households within each sublocation as shown in Table 1.

Table 1.

Sample sizes of the 10 sub-locations in Budalangi.

\begin{tabular}{|c|c|c|c|c|c|}
\hline Wards (strata) & Sublocation & Population & $\begin{array}{l}\text { Number of } \\
\text { households }\end{array}$ & $\begin{array}{c}\text { Sample } \\
\text { size }\end{array}$ & Percentage \\
\hline \multirow[t]{4}{*}{ North Bunyala } & Mudere & 1,665 & 339 & 4 & 4 \\
\hline & Budalangi & 5,608 & 1,247 & 15 & 15 \\
\hline & Mudembi & 4,113 & 936 & 11 & 11 \\
\hline & Ruambwa & 5,022 & 1,135 & 14 & 11 \\
\hline \multirow[t]{3}{*}{ South Bunyala } & Rukala & 3,071 & 680 & 9 & 9 \\
\hline & Lugale & 2,325 & 520 & 6 & 6 \\
\hline & Mabinju & 3,225 & 756 & 9 & 9 \\
\hline \multirow[t]{2}{*}{ Central Bunyala } & Magombe West & 4,344 & 1,063 & 13 & 13 \\
\hline & Magombe Central & 3,458 & 785 & 10 & 10 \\
\hline \multirow[t]{2}{*}{ West Bunyala } & Singinga & 3,531 & 779 & 9 & 9 \\
\hline & \multicolumn{2}{|l|}{ Total } & 8,240 & 100 & 100 \\
\hline
\end{tabular}

\subsection{Questionnaire design}

The questionnaire contains close-ended questions for socio-psychological factor assessment (see Table 2). The socio-psychological factors considered in this study included the perceived self-efficacy, the perceived response cost, the flood experience, the worry, and the perceived flood consequences. In this research, every interviewed household were assumed to be influenced by one-time flooding each year. The interviewees were also asked to state the flood mitigation measures that they had implemented to protect themselves from flooding. 


\subsection{Data collection, entry, and analysis}

Household survey was conducted during a period of December 2018 and January 2019 using face-to-face interview technique, from 100 households. Data collected from the field was coded on the variable view of Statistical Package for the Social Sciences (SPSS). The socio-psychological variables were coded as indicated in Table 2. The dependent variable (flood mitigation measures) was ranked from 0 to 9. The Spearman correlation was used in this research, since the collected data was not normally distributed. In addition, the Spearman correlation is suitable for ordinal data. The Spearman correlation was determined by the SPPS and used for evaluating the relationship between socio-psychological variables and the number of mitigation measures. A method developed by Dancey, et al. (2007) was used to interpret Spearman correlation coefficient as presented in Table 3.

Table 2.

Summary of field data questions and their coding values.

\begin{tabular}{|l|l|l|}
\hline \multicolumn{1}{|c|}{$\begin{array}{c}\text { Independent } \\
\text { Variable }\end{array}$} & \multicolumn{1}{|c|}{ Question } & \multicolumn{1}{c|}{ Coding } \\
\hline $\begin{array}{l}\text { Perceived Self- } \\
\text { Efficacy }\end{array}$ & $\begin{array}{l}\text { Do you agree with this statement? I can } \\
\text { cope up with negative impacts of floods. }\end{array}$ & $\begin{array}{l}\text { 1. Strongly disagree, 2. } \\
\text { Disagree, 3. Neutral, 4. Agree, } \\
\text { 5. Agree, 6. Strongly agree }\end{array}$ \\
\hline $\begin{array}{l}\text { Perceived } \\
\text { Response Cost }\end{array}$ & $\begin{array}{l}\text { How do you perceive the overall cost of } \\
\text { implemented mitigation measure? }\end{array}$ & $\begin{array}{l}\text { 1. Not costly, 2. Slightly } \\
\text { costly 3. Costly, 4. Very costly }\end{array}$ \\
\hline $\begin{array}{l}\text { Flood } \\
\text { Experience }\end{array}$ & $\begin{array}{l}\text { How many times have you experience } \\
\text { flooding event? }\end{array}$ & $\begin{array}{l}\text { 0. No experience, 1. Once, } 2 . \\
\text { Twice, 3. Thrice, 4. 4 times, 5. } \\
\text { 5 times, 6. over 5 times }\end{array}$ \\
\hline $\begin{array}{l}\text { Perceived } \\
\text { Consequences }\end{array}$ & $\begin{array}{l}\text { How likely do you perceive an increase } \\
\text { of material/ financial or health damage } \\
\text { due to future flood occurrence for your }\end{array}$ & $\begin{array}{l}\text { 1. Very unlikely, 2 Rather } \\
\text { unlikely, 3. Moderate likely, 4. } \\
\text { Rather likely, 5. Very likely }\end{array}$ \\
\hline Worry & $\begin{array}{l}\text { Are you worried about flood risk in your } \\
\text { village? }\end{array}$ & $\begin{array}{l}\text { 1. Not worried, 2. Slightly } \\
\text { worried, 3. Worried, 4. A lot }\end{array}$ \\
\hline
\end{tabular}

Table 3.

Interpretation of spearman correlation coefficient in psychology (Dancey et al. 2017).

\begin{tabular}{|c|c|c|}
\hline Level of Strength & \multicolumn{2}{|c|}{ Correlation Coefficient } \\
\hline Zero & 0 & 0 \\
\hline Weak correlation & +0.1 to +0.3 & -0.1 to -0.3 \\
\hline Moderate correlation & +0.4 to +0.6 & -0.4 to -0.6 \\
\hline Strong correlation & +0.7 to +1.0 & -0.7 to -1.0 \\
\hline
\end{tabular}




\section{RESULTS AND DISCUSSIONS}

\subsection{The study area}

\subsubsection{Socio-economical characteristics}

The percentage of male and female interviewees were $51 \%$ and $49 \%$, respectively. Most of the interviewed households have the family size of $6-10$ people. The $74 \%$ of the households were home owners.

\subsubsection{Number of Flood Experience}

The heads of the household were asked to state the number of flood events they have experienced from the past. The interviewed results show that, $3 \%$ of the households had no flood experiences, $8 \%$ of them had experienced once, $7 \%$ of the interviewed households stated that they had experienced twice. Majority of the household mentioned that they experienced flooding three times, which equivalent to $41 \%$ of the interviewed households. The $17 \%, 11 \%$, and $13 \%$ of the interviewed households experienced flooding 4 times, 5 times and over five times, respectively. The interviewed household experienced floods in 1997, 2000, 2002, 2003, 2010, 2017, 2018. Others also stated that they experienced floods yearly. Majority of the households stated that the impacts of floods included - properties damages, the death of people and animals, outbreak of the water-borne diseases (such as cholera and malaria), high remedial investment, and famine.

\subsubsection{Perceived Response Cost}

The household's representatives were asked to rate their perceived response cost in term of overall cost of flood mitigation. The $9 \%$ of the interviewed household stated that it was not costly, while $21 \%$ of them stated that it was slightly costly. On the other hand, $10 \%$ percent of them stated that it costly and $60 \%$ of them stated that it was very costly. The households with the perception of high response cost may attribute by their low incomes.

\subsubsection{Perceived Self- Efficacy}

The household representatives were asked to confirm that they can deal with flood impacts. The $26 \%$ of them stated that they strongly disagree, $29 \%$ of them stated that they disagree, while $26 \%$ of them stated that they agree. The agreed households believed that they could apply the mitigation measures to protect themselves and properties. On the other hand, the disagreed households cited their financial constraints as a huge impediment.

\subsubsection{Perceived Consequences}

In this research, the perceived consequences refer to expected flood consequences, such as property destruction and death. The $5 \%$ of household stated that it is unlikely to experience the increase damages from the future flooding events. The $15 \%$ of them stated that it is likely, while $80 \%$ of them stated that it is very likely to cause more damages. The high perceived consequences are caused by the of lack of permanent dykes to act as a protective barrier and the increased intensity of flooding events.

\subsubsection{Worry}

The household heads were asked whether they worried about the flood risk in Budalangi. The $60 \%$ of the household representatives stated that they worried a lot, while $32 \%$ of them stated that they worried. On the other hand, $2 \%$ and $6 \%$ of them stated that they slightly worried and not worried, respectively. Many households stated that, they 
worried about the floods because it had severe impacts on their lives, properties, crops and their financial.

\subsection{Flood mitigation measures}

The interviewees were asked to provide (more than one of) their mitigation measure during the flood events. According to the face-to-face interview results, the mitigation techniques implemented by the local are as followed - (1) constructing the drainage channels to improve the drainage system (73\%), (2) raising the house floors (35\%), (3) raising the electrical wiring system (29\%), (4) constructing the water resistant walls (31\%), (5) plating trees as a flood mitigation measures (57\%), and (6) relocating their houses $(66 \%)$. The $34 \%$ of households had precaution savings. Only $6 \%$ of the households had flood emergency plans. The $19 \%$ of the households had implemented at least 4 measures, while $2 \%$ of them had implemented a total of nine measures as presented in the Fig. 2.

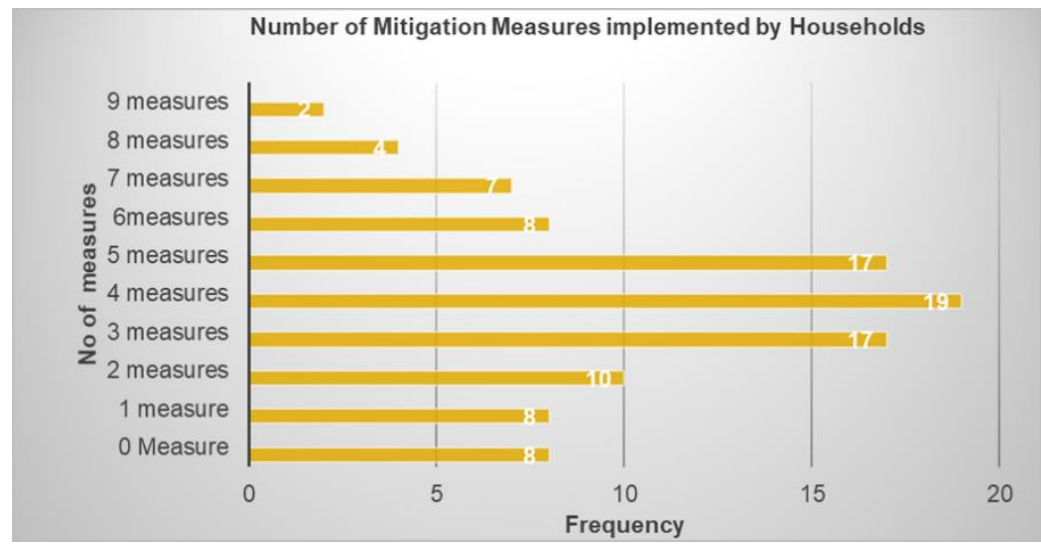

Fig. 2. The number of flood mitigation measures implemented by the interviewed households.

\subsection{Statistical analysis}

\subsubsection{Perceived Self-Efficacy}

It is strong positive correlation between perceived self-efficacy and the total number of implemented mitigation measures $\left(\mathrm{r}=0.815^{* *}\right)$. This correlation is statistically significant ( $p<0.01$ ) as shown in Table 4 . The results suggest that the number of implemented flood mitigation measures increases with the rise in self-efficacy. It means that the individuals who can cope with flood impacts are usually implemented more mitigation measures compared to the other. This finding is similar to the study results determined by Grothmann et al. (2006); Peak et al. (2010); Loke et al. (2012); Mishra et al. (2012); and Bubeck et al. (2013). The previous studies discovered that the perceived self-efficacy positively influences the uptake of mitigation measures due to their financial status or skill wise.

\subsubsection{Perceived Response Cost}

Table 4 illustrates that the perceived cost negatively correlated with a total number of mitigation measures at moderate level $(\mathrm{r}=-0.522 * *)$. The correlation is also statistically significant $(\mathrm{p}<0.01)$. The perceived response cost of mitigation measures increases with 
the decrease in flood mitigation measures implementation. Therefore, perceived response cost negatively influences the uptake of flood mitigation measures implementation. The findings also similar to the works done by Poussin et al. (2014).

\subsubsection{Flood Experience}

Flood experience positively correlated with the number of flood mitigation measures implemented by households in Budalangi $\left(r=0.444^{*}\right)$. The correlation was statistically significant $\mathrm{p}<0.01$ as indicated in Table 4.

The findings showed that experienced households implemented more flood mitigation measures. This finding is consistent with the works done by Poussin et al. (2014); Cameron, et al. (2012); and Kousky (2010). The results from previous research also show that flood experience positively impacts the mitigation behaviours. In addition, Grothmann, et al. (2006); Siegrist et al. (2008); and Brubeck et al. (2012) also found out that flood experience is statistically significance and positively correlates with the adoption of mitigation measures. Therefore, having flood experience increases the willingness to implement more measures.

Table 4.

Influence of socio-psychological variables on flood mitigation measures implementations

\begin{tabular}{|l|c|c|}
\hline \multirow{2}{*}{ Socio-psychological variables } & Total number of flood mitigation measures implemented. \\
\cline { 2 - 3 } & Correlation coefficient & Significant level (p) \\
\hline Perceived self-efficacy & $0.815^{* *}$ & 0.000 \\
\hline Perceived cost of response & $-0.522^{* *}$ & 0.000 \\
\hline Number of flood experience & $0.444^{* *}$ & 0.000 \\
\hline Worry & $0.320^{* *}$ & 0.001 \\
\hline Perceived consequences & 0.109 & 0.140 \\
\hline Statistically significant at $0.01 * *$ & \multicolumn{2}{|c|}{} \\
\hline
\end{tabular}

\subsubsection{Perceived Consequences}

It is evidently clear that the perceived consequence is not statistically significant ( $p>0.01$ ) when correlated with the total number of mitigation measures. This result is in line with the works done by Poussin, et al. (2014). The level of flood consequences was not related to the level of household preparedness to mitigate flooding.

\subsubsection{The worry}

The worry positively correlates with the total number of mitigation measures $\left(0.320^{* *}\right)$. It is also statistically significant $(\mathrm{p}<0.01)$. The results suggested that worry about flood risk increases the willingness to implement more mitigation measures.

\subsection{The barriers to implementing the flood mitigation measures}

Majority of the households $(71 \%)$ stated that financial issue was the key obstacle to implementing the flood mitigation measures. This was evidently true because most of the interviewees were low-income earners. The only $10 \%$ of the interviewed households stated that communication was a barrier. This because the local radio station regularly broadcasts necessary flood information in Kinyala language. The $53 \%$ of the households reported the lack of technology to build flood-protection houses with reasonable cost. The $30 \%$ of the 
households stated the lack of cost-effectiveness information on the specific mitigation measures. In addition, $32 \%$ of the households also stated the lack of mitigation tools, such as sandbags and trees seedling.

\section{CONCLUSIONS AND RECOMMENDATIONS}

The research study revealed that simple canal, tree plantation and temporary relocation are the most practical mitigation measures in Budalangi, Kenya. The interviewed results show that perceived self-efficacy has positive impacts to the uptake of mitigation measures. The flood experience and worry have moderate and weak influences, respectively. The perceived response cost has negative influence on the uptake of mitigation measures. On the other hand, perceived consequences are not correlated with the uptake of mitigation measures. The identified barriers to mitigation measures implementation include - (1) incentives, (2) financial issue, (3) lack of technology, (4) communication and information transferred. Future research should focus on household's perspectives on effectiveness of the mitigation measures implementation.

\section{REFERENCES}

Babcicky, P., and Seebauer, S. (2017) The two faces of social capital in private flood mitigation: Opposing effects on risk perception, self-efficacy, and coping capacity. Journal of Risk Research, 20(8), 1017-1037.

Becker, G., Aerts, J., and Huitema, D. (2014) Influence of flood risk perception and other factors on risk-reducing behavior: a survey of municipalities along the Rhine. Journal of Flood Risk Management, 7(1), 16-30.

Bogardi, J. J. (2004) Hazards, risks and vulnerabilities in a changing environment: the unexpected onslaught on human security? Global Environmental Change, 4(14), 361-365.

Bubeck, P., Botzen, W. J., and Aerts, J. C. (2012) A review of risk perceptions and other factors that influence flood mitigation behavior. Risk Analysis: An International Journal, 32(9), 1481-1495.

Bubeck, P., Botzen, W. J., Kreibich, H., and Aerts, J. C. (2013) Detailed insights into the influence of flood-coping appraisals on mitigation behavior. Global Environmental Change, 23(5), 1327 1338.

Ceola, S., Laio, F., and Montanari, A. (2014) Satellite nighttime lights reveal increasing human exposure to floods worldwide. Geophysical Research Letters, 41(20), 7184-7190.

Costache, R. (2014) Estimating Multiannual Average Runoff Depth in the Middle and Upper Sectors of Buzau River Basin. Geographia Technica, 9(2), 21-29.

Coumou, D., and Rahmstorf, S. (2012). A decade of weather extremes. Nature Climate Change, 2(7), 491.

Dancey, C. P., and Reidy, J. (2007) Statistics without maths for psychology. Pearson Education.

Elmer, F., Hoymann, J., Düthmann, D., Vorogushyn, S., and Kreibich, H. (2012) Drivers of flood risk change in residential areas. Natural Hazards and Earth System Sciences, 12(5), 1641-1657.

Grothmann, T., and Reusswig, F. (2006) People at risk of flooding: why some residents take precautionary action while others do not. Natural hazards, 38(1-2), 101-120.

Huho, J. M., and Kosonei, R. C. (2014) Understanding extreme climatic events for economic development in Kenya. IOSR Journal of Environmental Science, Toxicology and Food Technology, 8(2), 14-24. 
Kousky, C. (2010) Learning from extreme events: Risk perceptions after the flood. Land Economics, 86(3), 395-422.

Laska, S. B. (1990) Homeowner adaptation to flooding: an application of the general hazards coping theory. Environment and Behavior, 22(3), 320-357.

NTV (2018, May 27) 39,000 acres of crops destroyed by Budalangi floods [Video file] retrieved from https://www.youtube.com/watch?v=qPZbFETClkE

Mishra, S., and Suar, D. (2012) Effects of anxiety, disaster education, and resources on disaster preparedness behavior. Journal of Applied Social Psychology, 42(5), 1069-1087.

Muku, L. O., and Nyandwaro, G. (2013) River Flood Modelling with Mike 11: Case of Nzoia River (Budalangi) in Kenya. Civil and Environmental research, 3(12), 103 - 111.

Mukuna, T. E. (2015) Vulnerability Analysis of the Gender-Differentiated Impact of Flooding in Budalangi Flood Plains, Kenya. Journal of Emerging Trends in Educational Research and Policy Studies, 6(2), 201-216.

Mulilis, J. P., and Lippa, R. (1990). Behavioral change in earthquake preparedness due to negative threat appeals: A test of protection motivation theory. Journal of Applied Social Psychology, 20(8), 619-638.

Nistor, M-M., Rahardjo, H., Satyanaga, A., Leong, E.C., Hao, K.Z., Sham, A.W.L. and Wu, H. (2019) GIS-based approach to identify the suitable locations for soil sampling in Singapore. Geographia Technica, 14(1), 103-117, DOI: 10.21163/GT_2019. 141.08.

Nusit, K., Tantanee, S., Subsomboon, K., Leungvichcharoen, S. and Yiemwattana, S. (2019) The Design of Flood Protection along Nan River, Phitsanulok Province, Thailand Geographia Technica, 14, A special Issue On Sustainable Urban Development, 129 - 137.

Okumu, M. (2017). Assessing the Root Cause of Persistent Floods and Strategic Community-based Interventions in Bunyala, Busia County, Kenya. International Journal of Innovative Research and Development, 6(6), 250 - 254.

Opere, A. (2013) Kenya: A Natural Outlook: Chapter 21. Floods in Kenya, Developments in Earth Surface Processes, 16, 315 - 330 .

Opondo, D. (2013) Loss and Damage from Flooding in Budalangi District, Western Kenya Loss and Damage in Vulnerable Countries Initiative, Case study report. Bonn: United Nations University Institute for Environmental and Human Security.

Onywere, S.M., Getenga, Z.M., Mwakilala, S.S., Twesigye, C.K. and Nakiranda, J.K. (2011) Assessing the challenge of settlement in Budalangi and Yala swamp area in Western Kenya using Landsat satellite image. The Open Environmental Engineering Journal, 4, 97 - 104.

Opondo, D. O. (2013) Erosive coping after the 2011 floods in Kenya. International Journal of Global Warming, 5(4), 452 - 466.

Osberghaus, D. (2015) The determinants of private flood mitigation measures in Germany-Evidence from a nationwide survey. Ecological Economics, 110, 36 - 50.

Otiende, B. (2009) The economic impacts of climate change in Kenya: riparian flood impacts and cost of adaptation. online] adapt. org/knowledge-base/files/758/4e25a4b8c8bf61Ckenyariparian-floods-case-study. pdf (accessed August 2013).

Poussin, J. K., Botzen, W. W., and Aerts, J. C. (2014) Factors of influence on flood damage mitigation behaviour by households. Environmental Science \& Policy, 40, 69 - 77.

Richert, C., Erdlenbruch, K., and Figuières, C. (2017) The determinants of households' flood mitigation decisions in France-on the possibility of feedback effects from past investments. Ecological Economics, 131, 342 - 352.

Rippetoe, P. A., and Rogers, R. W. (1987) Effects of components of protection-motivation theory on adaptive and maladaptive coping with a health threat. Journal of personality and social psychology, 52(3), 596 - 604. 
Rogers, R. W. (1975) A protection motivation theory of fear appeals and attitude change. The journal of psychology, 91(1), 93-114.

Rogers, R. W. (1983) Cognitive and psychological processes in fear appeals and attitude change: A revised theory of protection motivation. Social psychophysiology: A sourcebook, 153-176.

Siegrist, M., and Gutscher, H. (2008). Natural hazards and motivation for mitigation behavior: People cannot predict the affect evoked by a severe flood. Risk Analysis: An International Journal, 28(3), 771-778.

Şarpe, C.A., and Haidu, I., (2017) Temporal sampling conditions in numerical integration of hydrological systems time series. Geographia Technica, 12(1), 82- 94, DOI: 10.21163/GT_2017.121.09

Kenya National Bureau of Statistics. (2010) The 2009 Kenya population and housing census: Kenya National Bureau of Statistics Kenya.

Taki, K., Matsuda, T., Ukai, E., Nishijima, T., and Egashira, S. (2013) Method for evaluating flood disaster reduction measures in alluvial plains. Journal of Flood Risk Management, 6(3), 210 218.

Wiegman, O., Taal, E., van den Bogaard, J., Gutteling, J. M., Winnubst, J., and Maes, S. (1992) Protection motivation theory variables as predictors of behavioral intentions in three domains of risk management, in J.A.M. Winnubst and S. Maes (eds.), Lifestyles, stress, and health: New developments in health psychology, DSWO/Leiden University Press, Leiden, The Netherlands, 55-70.

Yamane, T. (1973) Statistics: An introductory analysis. $3^{\text {rd }}$ Edition, Harper and Row, New York. 